\title{
Environmental knowledge level in undergraduate students: University of San Pedro, Peru
}

\author{
Nível de conhecimento ambiental em estudantes de graduação: Universidade \\ de San Pedro, Peru
}

\author{
Oscar Julián Berrios Tauccaya' \\ David Roberto Ricse Reyes" \\ Leandro Alonso Vallejos More ${ }^{\text {III }}$ \\ Prospero Cristhian Onofre Zapata MendozaIV
}

\begin{abstract}
Studies specifically referring to the evaluation of learning levels and awareness of university students in environmental matters are incipient. In that order, the objective of this research is to establish the influence curriculum of the San Pedro University, Sullana subsidiary on the level of environmental knowledge of undergraduate students, 2017. The research design is non-experimental, applicative, observational and descriptive. The study population corresponds to undergraduate students of the San Pedro University, Sullana, 2018. The total population comprises 2050 students; the sample is structured by a non-probabilistic sample, represented by 188 undergraduate students of the San Pedro University Sullana 2017, students from different Professional Schools. The survey technique was applied, through a knowledge assessment questionnaire on environmental issues. With a significance level of 0.05 , it was demonstrated that the Study Plan of the San Pedro University subsidiary Sullana 2017 doesn't have any significant influence on the level of environmental knowledge of undergraduate students. With an average of $2.73 \%$ of the courses dedicated to the environmental issue, it is concluded that environmental issues are not a priority within the curricular contents of the San Pedro University, Sullana subsidiary.
\end{abstract}

Keywords: Environment; Knowledge; Evaluation; Students; University

\section{Resumo}

Os estudos referentes especificamente à avaliação dos níveis de aprendizagem e conscientização dos estudantes universitários em questões ambientais são incipientes. Nessa ordem, o objetivo desta pesquisa é I Biólogo, Facultad de Ingeniería, Universidad Nacional de Frontera, Sullana, Piura, Perú innovasciencia@gmail.com

II Ingeniero Químico, Facultad de Ingeniería, Universidad Nacional de Frontera, Sullana, Piura, Perú daric_quimico@hotmail.com

IIIIngeniero Agroindustrial, Facultad de Ingeniería, Universidad Nacional de Frontera, Sullana, Piura, Perú Ivallejos@mba.pad.edu

IVArquitecto, Facultad de Ingeniería, Universidad Nacional de Frontera, Sullana, Piura, Perú criszamen2@gmail.com 
estabelecer a influência do currículo da Universidade de San Pedro, ramo Sullana no nível de conhecimento ambiental dos estudantes de graduação, 2017. O desenho da pesquisa é não experimental, aplicativo, observacional e descritivo. A população do estudo corresponde aos estudantes de graduação da Universidade de San Pedro, rama Sullana, 2018. A população total é composta por 2050 estudantes, a amostra é estruturada por uma amostra não probabilística, representada por 188 estudantes de graduação da Universidade San Pedro Sullana ramo ano 2017, estudantes de diferentes Escolas Profissionais. A técnica de levantamento foi aplicada por meio de um questionário para avaliar o conhecimento sobre questões ambientais. Com um nível de significância de 0,05 foi demonstrado que o plano de estudo da Universidade de San Pedro ramo Sullana 2017, não influencia significativamente o nível de conhecimento ambiental dos estudantes de graduação. Com uma média de $2,73 \%$ dos cursos dedicados às questões ambientais, pode-se deduzir que as questões ambientais não são uma prioridade nos conteúdos curriculares da delegação da Universidade de San Pedro em Sullana.

Palavras-chave: Ambiente; Conhecimento; Avaliação; Estudantes; Universidade 


\section{Introduction}

The industrialization effects and the exponential growth of the human population on the sustainability of the planet are undeniable. The Intergovernmental Panel on Climate Change (IPCC) report (2018) refers to the estimated risks to climatic changes as a result of $1.5^{\circ}$ temperature raise. The potential threats associated with the increase in temperature are estimated differentiated according to the regions, levels of development, public policies of eco sustainability and mitigation (UN, 2018). In that order, the IPCC in the report published in the year 2018, refers to global warming as a result of human action reaching between $0.8^{\circ}$ and $1.2^{\circ}$ in 2017 , in relation to the 1850-1900 stage (IPCC, 2018). The report emphasizes the increase in temperature of approximately $20 \%$ since 2000 . In addition to this, IPCC estimates that climatic changes are expressed asymmetrically, according to the geographical region with fluctuations above the average that reach up to $6^{\circ}$ of difference. The number of hot days will increase in most regions and flood areas will increase in number, in proportion to the increase in temperature, being estimated to reach $0.77 \mathrm{~m}$ by the year 2100 (IPCC, 2018). Literature in climate change field is profuse and in general the authors agree that role education plays in the dissemination of the culture of environmental sustainability. However, studies specifically referring to the evaluation of the levels of learning and awareness of students in environmental matters are incipient (MSENGI et al., 2019; AFNAN et al., 2017; RAUF et al., 2017; ESTRADA \& TOJAR, 2017). Nonetheless, this status of affairs tends to change, whether due to focus changes or regulatory induction. In terms of approach, the enrollment of educational institutions within new perspectives where the didactic suitability in addressing environmental issues tend to move from the academic transverse to the holistic of human work, establishing a roadmap that transcends the strictly academic.

There is a consensus among most researchers in characterizing the anthropogenesis of climate change produced since the 19th century. The univocity among those who attribute the negative environmental impact to human actions is divided into a plurality of conceptions, proposals and corrective actions (ROSENTRATER \& BURKE, 2017). This plurality affects the efficiency of environmental education as a transversal axis of educational 
curricula. Among researchers there is a consensus on the need to educate teachers with the necessary tools so that the mainstreaming of the environment and the universalism of environmental responsibility will accompany the development of class sessions as a substantial element of the curriculum, where the Echocentric positioning results in environmental behaviors by students (LEAL et al., 2018; ORANGES et al., 2018; STOUGH et al., 2018; PULIDO \& OLIVERA, 2018).

Environmentalist behaviors are a consequence of a multiplicity of factors that affect the conformation of personality. Carhuapoma and Juárez (2015) found out that among Peruvian university students who express high levels of benevolence and universalism within the Shwartz scale of values, environmental behaviors which are manifested, are expressed in environmental actions. Subsequently, Álvarez, López and Chafloque (2018) diagnosed how the environmentalist behavior modalities of Peruvian university students of the Business Sciences and Engineering degrees nationwide are expressed. 52.9\% of the surveyed students indicated that they always or almost always observe environmental behavior of various orders; however, to the question about the role of social influence on environmental behaviors, $44 \%$ indicated that they receive pro-environmental influence from of peers and teachers, the teaching influence prevailing in $47.7 \%$ of cases (ÁLVAREZ et al., 2018). These results show that less than $50 \%$ of students recognize teachers as referents in environmental matters, and less than $25 \%$ of students stated that they carry out environmental actions.

Plurality in environmental matters prevails strictly in the academic field. Several investigations agree that the effectiveness of programmatic content in environmental matters requires the integration of institutional and individual efforts (STOUGH et al., 2018; CÓNDOR, 2018; HOOVER \& HARDER, 2015; FISCHER et al., 2015). The goal is to establish agreed frameworks for action, breaking with the tendency towards the individualization of teaching strategies for environmental education and with the conceptual plurality of sustainability, both generating tensions that demand dialogic actions within institutions (ORANGES et al., 2018).

The conceptual plurality in environmental matters leads to diverse responses in relation to environmental and sustainability issues by university students. Richard and Adams (2011), demonstrated that in geographically distant university institutions -Hawaii and 
Alabama-, where student concerns about the theme of environmental sustainability are common; this concern does not translate into actions in the same proportions in both institutions. Indeed, when urged towards active participation in the development of actions that affect environmental sustainability, the students of the Hawaiian university institution proved proactive to environmental sustainability practices, while Alabama students were reluctant to assume eco-sustainable performances. The divergence of attitudes is attributed to the differentiation between the socialization spaces of both groups, while students who grew up in contact with nature tend to empathize more with environmental sustainability actions than students who have not experienced experiences with nature (POSKUS, 2019; PRÉVOT et al., 2016). In another order, Jackson et al. (2016), describe a similar experience with students from the last secondary stage of Hong Kong, who didn't show a direct correlation between environmental attitudes and behavior.

The divergence in the levels of student proactivity against concrete actions oriented towards environmental sustainability expresses the multiplicity of preconceptions, diversity of contexts, socially diverse spaces and focus plurality with which the mainstreaming of the environmental is incorporated in the university curricular contents. The wide controversy among researchers about the relationship between attitudes and environmental behavior of university students expresses the demand for uniformity of didactic criteria within the crosscurricular mesh of environmental issues, and demonstrates the need to deepen the assessment of environmental knowledge achieved by university students (STOUGH et al., 2018; FISCHER et al., 2015).

In that order, Stough et al. (2018) demonstrated that there is no uniformity of criteria for the evaluation of knowledge on environmental sustainability in the curricular contents of university degrees. The authors argue that in principle there is no univocity in the conceptualization of sustainability, coupled with the fact that reports referring to integration degrees of the curriculum subject are measured based on the presence or not of courses related to sustainable development, which it doesn't refer to the levels of knowledge achieved by students on the subject. These results show the existing gap in the matter of instruments that study concomitantly both inputs and products associated with the teaching-learning of sustainable development. Prevot, Clayton and Mathevet (2016) refers 
that the effectiveness of environmental education should be measured by other indicators different to the degree, indicating that the sense of identity with the environmental issue is built from childhood in an identity process, where professional career selection studied, is associated with the development of the environmental identity, from which it follows that the environmental identity precedes the university career. This doesn't detract from the construction of environmental identities in adulthood, only that this process transits through the development of individual or group experiences of interaction with nature, which demonstrates the inadequacy of environmental education and sustainability from the classroom settings, without this educational process being accompanied by field experiences (PREVOT et al., 2016).

In Peru, from a normative perspective, educational institutions have Law 28044 of the year 2003 where the principle of environmental awareness is established. Other environmentalist vocation laws were established in the following years, being the National Environmental Action Plan [NEAPLAN] 2011-2021 the instrument of national environmental planning with the greatest impact, as part of the diagnosis of the country's environmental situation and from there; it establishes specific objectives to achieve the proposed environmental sustainability goals. In university matters, environmental sustainability policies are contained within the guideline 10 of the National Environmental Education Policy (2012), which includes the modification of "Develop the environmental approach in professional training, research, social projection and institutional management of the entities of university and non-university higher education "(MINISTRY OF EDUCATION OF PERU, 2012).

Registered within the purpose of promoting achievements in university sustainability, the Interuniversity Environmental Network (2018) publishes the annual ranking of environmental sustainability of universities based on the indicators: 1. Internal environmental management, 2. Training, 3. Research and 4. Cultural extension and social projection. This allows identifying the manifestation of pro-environmental actions derived from the holistic conception of university environmental sustainability.

In accordance with national regulations, Peruvian universities have implemented transversal axes within the curricula of the different university degrees. However, this 
transversality continues to be evaluated by the presence or absence of environmental courses within the curricula, as indicated by Stough et al. (2018) and Fischer et al. (2015), without evaluating the levels of environmental knowledge of the students.

Within this context, the objective of this research is to establish the influence curriculum of the University San Pedro, Sullana subsidiary on the level of environmental knowledge of undergraduate students, 2017.

\section{Materials and Methods}

The research design is non-experimental, applicative, observational and descriptive. In addition, a Spearman correlation analysis and a Generalized Linear Mixed Models test was performed to establish relationship between the two variables. The study population corresponds to the undergraduate students of the San Pedro University, Sullana subsidiary, 2018. The entire population comprises 2050 students; the sample is structured by a nonprobabilistic sample, represented by 188 undergraduate students of the San Pedro Sullana subsidiary, year 2017, students from different Professional Schools.

The survey technique was applied, applying an evaluation questionnaire with structured questions according to the designs used in previous works (LIARAKOU et al., 2011). The questionnaire was structured in two sections of 12 multiple-choice questions and 12 true and false questions (see Table 1).

(Continue...) 
Table 1 - Knowledge level questionnaire on environmental issues in university students of San Pedro University 2018.

\begin{tabular}{|c|c|c|}
\hline $\begin{array}{l}\text { claration on } \\
\text { and } \\
\text { of Janeiro } \\
\text { ange was } \\
\text { he countries } \\
\text { R: No } \\
\text { enhouse } \\
\text { the number } \\
\text { vho get } \\
\text { ? R: Yes } \\
\text { n of } \\
\text { ne } \\
\text { cattle }\end{array}$ & $\begin{array}{l}\text { 13. The carbon footprint } \\
\text { refers to: } \\
\text { a. Dating of } \\
\text { archaeological objects. } \\
\text { b. Pesticides } \\
\text { c. Sunscreen measure. } \\
\text { d. Measurement of } \\
\text { greenhouse gas } \\
\text { emissions. R: b } \\
\text { 14. The hole in the ozone } \\
\text { layer was caused by: } \\
\text { a. Rocket } \\
\text { b. Hot air balloons } \\
\text { c. CO } 2 \\
\text { d. Overpopulation. R: c } \\
\text { 15. The Mad Cows } \\
\text { disease was caused by: } \\
\text { a. Greenhouse effect. } \\
\text { b. The grass } \\
\text { c. Prions } \\
\text { d. Phosphates R: c } \\
\text { 16. Melanoma is } \\
\text { associated with: } \\
\text { a. Skin weakening } \\
\text { b. Ozone layer weakening. } \\
\text { c. Air weakening. } \\
\text { d. Water weakening. R: b } \\
\text { 17. The reduction in the } \\
\text { use of plastic bags can be } \\
\text { achieved by: } \\
\text { a. Luxury tax } \\
\text { b. Industry Tax } \\
\text { d. }\end{array}$ & 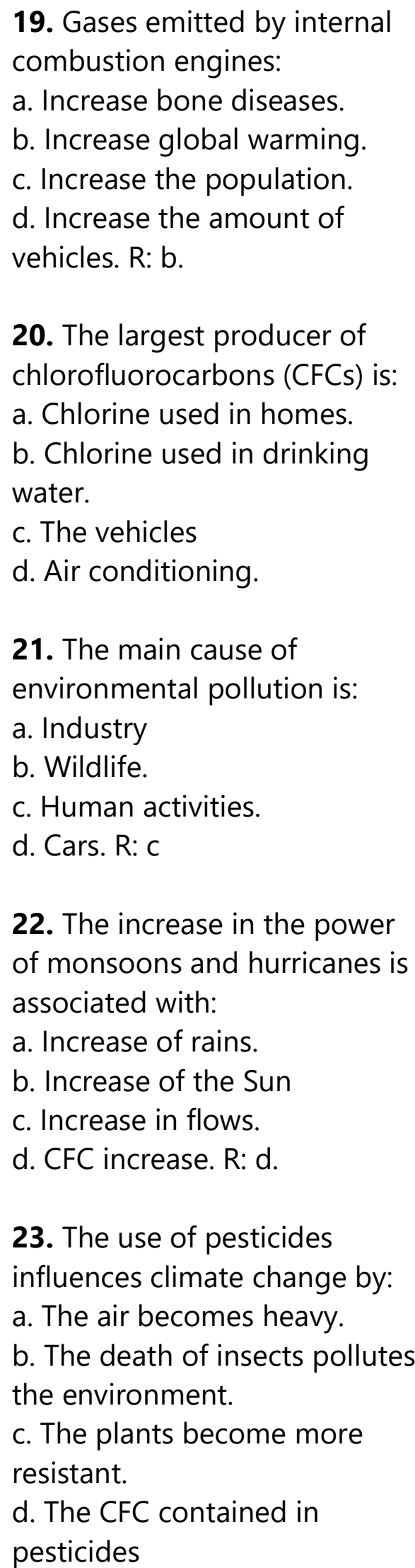 \\
\hline
\end{tabular}


9. The environmental tax contributes to the reduction of the greenhouse effect. R: Yes.

10. Humanistic disciplines do not influence the decrease of the greenhouse effect. R: No

11. The use of recycled materials decreases the amount of plastics in the Ocean. R: Yes

12. The increase in the greenhouse effect increases the amount of drinking water available in cities. R: No.
18. What public policy do you think may influence the reduction of pollution?

a. Criminalization of the consumption of soft drinks.

b. Penalization of the consumption of bottled water.

c. Award for ecoefficient behaviors. d. Campaign awards agai nst bulling. $R$ : $c$.
24. The human activities that influence the increase of the CFC are:

a. Education.

b. Farming.

c. Transport.

d. All of the above. R: $d$.

The data obtained were analyzed and processed through statistical tools, through specialized software.

\section{Results and Discussion}

3.1 Analysis and processing of the curriculum of the University of San Pedro, Sullana subsidiary.

Table 2 - Curriculum Analysis 2014. 


\begin{tabular}{|c|c|c|c|c|c|c|}
\hline & & & Courses & Cycle & $\%$ & $\begin{array}{c}\% \\
\text { Total }\end{array}$ \\
\hline 1 & Civil Engineering & 70 & Environmental management & IX & 1.43 & 1.43 \\
\hline 2 & $\begin{array}{c}\text { Computer and Systems } \\
\text { Engineering }\end{array}$ & 59 & 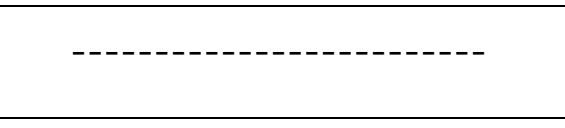 & - & 0.00 & 0.00 \\
\hline 3 & $\begin{array}{l}\text { Architecture and } \\
\text { Urbanism }\end{array}$ & 59 & $\begin{array}{c}\text { Ecology and Urban } \\
\text { Geography } \\
\text { Environmental conditioning I } \\
\text { Environmental conditioning } \\
\text { II } \\
\text { Heritage Preservation }\end{array}$ & $\begin{array}{l}\text { III } \\
\text { V } \\
\text { VII }\end{array}$ & $\begin{array}{l}1.69 \\
1.69 \\
1.69 \\
1.69\end{array}$ & 6.76 \\
\hline 4 & Agronomic Engineering & 66 & $\begin{array}{c}\text { Biology } \\
\text { General Ecology } \\
\text { Water and Soil Management } \\
\text { and Conservation II } \\
\text { Agroecology } \\
\text { Water and Soil Management } \\
\text { and Conservation II }\end{array}$ & $\begin{array}{l}\mathrm{I} \\
\mathrm{I} \\
\mathrm{IV} \\
\mathrm{VI}\end{array}$ & $\begin{array}{l}1.51 \\
1.51 \\
1.51 \\
1.51 \\
1.51\end{array}$ & 7.55 \\
\hline 5 & Industrial engineering & 71 & Environmental engineering & VII & 1.41 & 1.41 \\
\hline 6 & Nursing & 46 & $\begin{array}{l}\text { Biology } \\
\text { Bioethics }\end{array}$ & I IV & $\begin{array}{l}2.17 \\
2.17\end{array}$ & 4.34 \\
\hline 7 & $\begin{array}{l}\text { Tec. Med. Clinical } \\
\text { Laboratory and } \\
\text { Pathological Anatomy }\end{array}$ & 51 & General biology & I & 1.96 & 1.96 \\
\hline 8 & Obstetrics & 48 & General biology & 1 & 2.08 & 2.08 \\
\hline 9 & $\begin{array}{l}\text { Pharmacy and } \\
\text { Biochemistry }\end{array}$ & 60 & $\begin{array}{c}\text { Ecology } \\
\text { Edaphology }\end{array}$ & $\begin{array}{l}x \\
x\end{array}$ & $\begin{array}{l}1.67 \\
1.67\end{array}$ & 3.34 \\
\hline 10 & Psychology & 74 & Biology & 1 & 1.35 & 1.35 \\
\hline 11 & Initial education & 75 & $\begin{array}{c}\text { Environmental education } \\
\text { Science and Environment } \\
\text { Teaching }\end{array}$ & II & $\begin{array}{l}1.33 \\
1.33\end{array}$ & 2.66 \\
\hline
\end{tabular}




\begin{tabular}{|c|c|c|c|c|c|c|}
\hline \multirow{3}{*}{12} & & & Environmental education & 1 & 1.30 & \multirow{3}{*}{3.90} \\
\hline & Primary education & 77 & $\begin{array}{l}\text { Didact. of Science and } \\
\text { Environment I }\end{array}$ & VII & 1.30 & \\
\hline & & & $\begin{array}{c}\text { Didact. of Science and } \\
\text { Environment II }\end{array}$ & IX & 1.30 & \\
\hline 13 & Right & 85 & Environmental law & V & 1.18 & 1.18 \\
\hline 14 & Administration & 50 & --- & - & 0.00 & 0.00 \\
\hline \multirow{2}{*}{15} & \multirow{2}{*}{ Accounting } & \multirow{2}{*}{61} & Environmental Accounting & VIII & 1.64 & \multirow{2}{*}{3.28} \\
\hline & & & Environmental Audit & IX & 1.64 & \\
\hline & $\Sigma$ & 952 & 26 & & $2.73 \%$ & \\
\hline
\end{tabular}

Figure 1 Curriculum Analysis 2014.

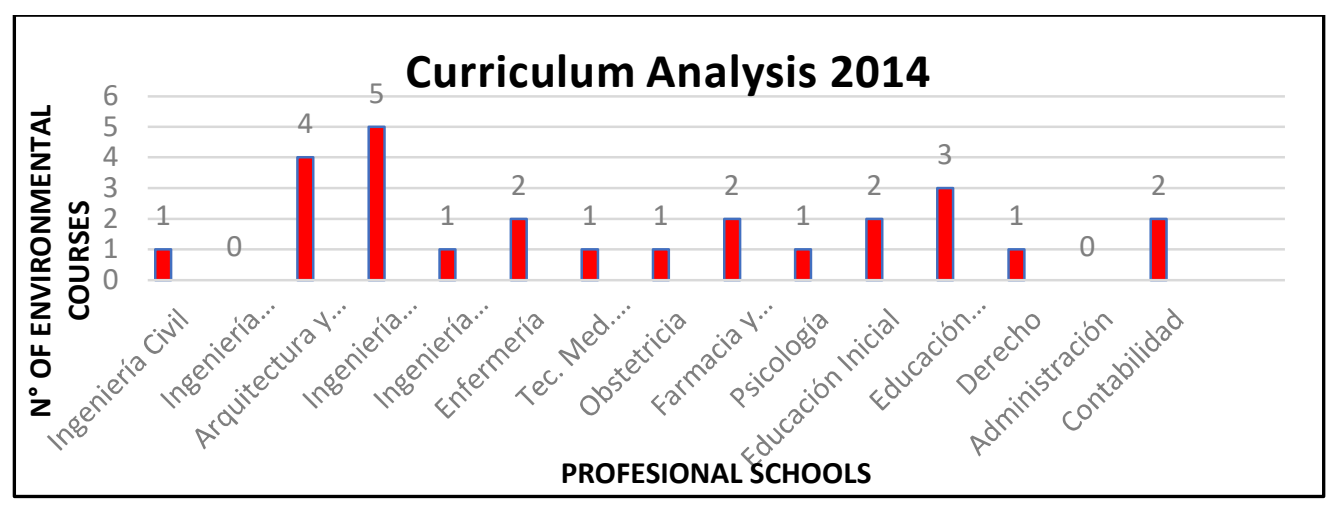

Interpretation: Table 2 and Figure N 1 show the analysis and processing of the number of subjects of environmental interest by the Professional School, observing that the Agronomy Professional School and the one of Architecture and Urbanism are the schools with the highest number of subjects of environmental interest, 5 and 4 respectively.

Table 2 - Frequencies of Notes of the Knowledge Level on Environmental Issues

\begin{tabular}{cccccccc}
\hline $\mathbf{N}^{\circ}$ & NOTES (Xi) & $\mathbf{f i}$ & $\mathbf{F i}$ & $\mathbf{\%} \mathbf{f i}$ & $\mathbf{h i}$ & $\mathbf{H i}$ & $\mathbf{\%} \mathbf{h i}$ \\
\hline 1 & 4 & 5 & 5 & 2.66 & 0.027 & 0.027 & 2.7 \\
\hline 2 & 5 & 3 & 8 & 1.6 & 0.016 & 0.043 & 1.6 \\
\hline
\end{tabular}




\begin{tabular}{lccccccc}
\hline 3 & 6 & 7 & 15 & 3.72 & 0.037 & 0.08 & 3.7 \\
\hline 4 & 7 & 5 & 20 & 2.66 & 0.027 & 0.107 & 2.7 \\
\hline 5 & 8 & 19 & 39 & 10.11 & 0.101 & 0.208 & 10.1 \\
\hline 6 & 9 & 21 & 60 & 11.17 & 0.112 & 0.32 & 11.2 \\
\hline 7 & 10 & 22 & 82 & 11.7 & 0.117 & 0.437 & 11.7 \\
\hline 8 & 11 & 28 & 110 & 14.89 & 0.149 & 0.586 & 14.9 \\
\hline 9 & 12 & 23 & 133 & 12.23 & 0.122 & 0.708 & 12.2 \\
\hline 10 & 13 & 20 & 153 & 10.64 & 0.106 & 0.814 & 10.6 \\
\hline 11 & 14 & 14 & 167 & 7.45 & 0.074 & 0.888 & 7.4 \\
\hline 12 & 15 & 12 & 179 & 6.38 & 0.064 & 0.952 & 6.4 \\
\hline 13 & 16 & 8 & 187 & 4.26 & 0.043 & 0.995 & 4.3 \\
\hline 14 & 17 & 1 & 188 & 0.53 & 0.005 & 1 & 0.5 \\
\hline$\Sigma$ & & 188 & & 100 & 1.0 & & 100 \\
\hline
\end{tabular}

Figure 2 Knowledge Level Notes on Environmental Issues.

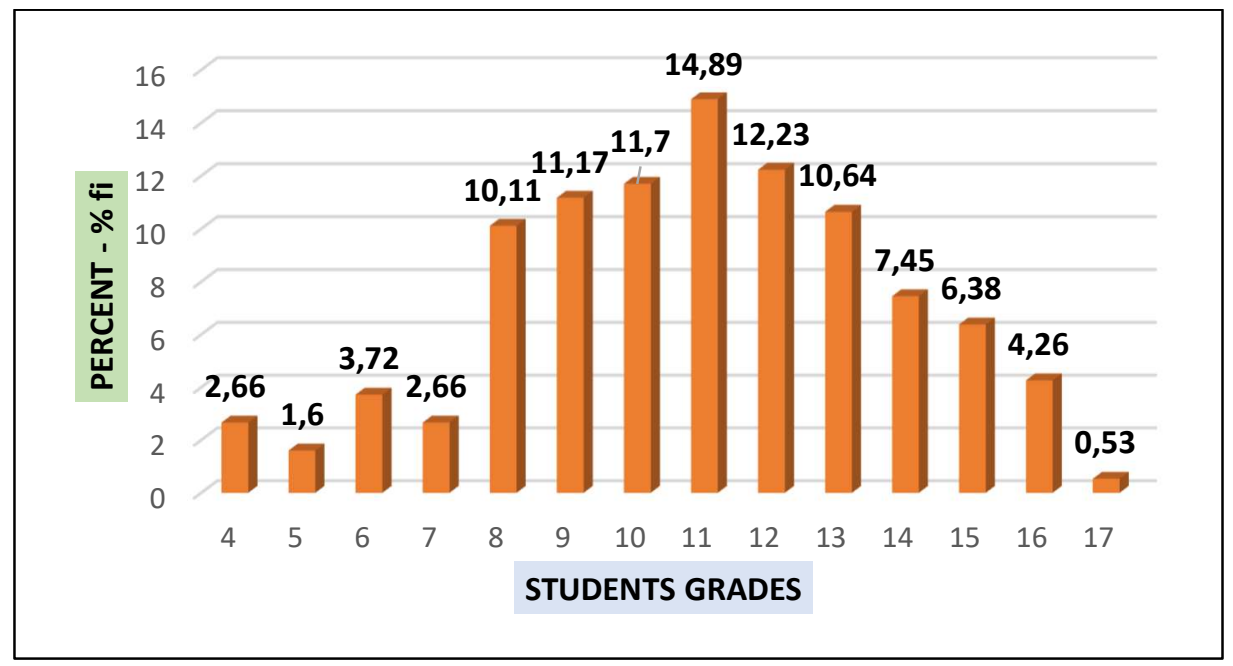

Interpretation: Table 3 and Figure 2 indicate the frequency and percentages of the grades obtained by the students belonging to the sample under study. 5 of the students obtained the minimum grade of 05 , representing $2.66 \%$ and 1 the maximum of 17 representing $0.53 \%$; and the grade of 11 is the one with the highest number of students (28), which represents $14.89 \%$. 
3.2 Analysis and Processing of the Level Notes on Environmental Issues

Table 4 - Frequency for the Calculation of the Average, Mode and Median.

\begin{tabular}{lccc}
\hline $\mathbf{N}^{\circ}$ & $\mathbf{X i}$ & $\mathbf{f i}$ & $\mathbf{X i ~} \mathbf{~ f i}$ \\
\hline 1 & 4 & 5 & 20 \\
\hline 2 & 5 & 3 & 15 \\
\hline 3 & 6 & 7 & 42 \\
\hline 4 & 7 & 5 & 35 \\
\hline 5 & 8 & 19 & 152 \\
\hline 6 & 9 & 21 & 189 \\
\hline 7 & 10 & 22 & 220 \\
\hline 8 & 11 & 28 & 308 \\
\hline 9 & 12 & 23 & 276 \\
\hline 10 & 13 & 20 & 260 \\
\hline 11 & 14 & 14 & 196 \\
\hline 12 & 15 & 12 & 180 \\
\hline 13 & 16 & 8 & 128 \\
\hline 14 & 17 & 188 & \\
\hline & $\Sigma$ & & 2038 \\
\hline
\end{tabular}

3.2.1 Dispersion Statisticians

Table 5 - Frequency to Calculate Variance, Standard Deviation and Variation Coefficient.

\begin{tabular}{|c|c|c|c|c|c|}
\hline $\mathbf{X i}$ & $\dot{\mathbf{x}}$ & fi & $\mathbf{X i}-\dot{\mathbf{x}}$ & $(X i-\dot{x}) 2$ & $(X i-\dot{x}) 2 \times f i$ \\
\hline 4 & 10.84 & 5 & -6.84 & 46.79 & 233.93 \\
\hline 5 & 10.84 & 3 & -5.84 & 34.11 & 102.32 \\
\hline 6 & 10.84 & 7 & -4.84 & 23.43 & 163.98 \\
\hline
\end{tabular}




\begin{tabular}{lccccc}
\hline 7 & 10.84 & 5 & -3.84 & 14.75 & 73.73 \\
\hline 8 & 10.84 & 19 & -2.84 & 8.07 & 153.25 \\
\hline 9 & 10.84 & 21 & -1.84 & 3.39 & 71.10 \\
\hline 10 & 10.84 & 22 & -0.84 & 0.71 & 15.52 \\
\hline 11 & 10.84 & 28 & 0.16 & 0.03 & 0.72 \\
\hline 12 & 10.84 & 23 & 1.16 & 1.35 & 30.95 \\
\hline 13 & 10.84 & 20 & 2.16 & 4.67 & 93.31 \\
\hline 14 & 10.84 & 14 & 3.16 & 9.99 & 139.80 \\
\hline 15 & 10.84 & 12 & 4.16 & 17.31 & 207.67 \\
\hline 16 & 10.84 & 8 & 5.16 & 26.63 & 213.00 \\
\hline 17 & 10.84 & 1 & 6.16 & 37.95 & 37.95 \\
\hline$\Sigma$ & & 188 & & 229.12 & 1537.21 \\
\hline
\end{tabular}

Source: prepared by the researcher (2016).

Prepared by: OJBT

The Variance obtained was $S^{\wedge} 2=8.22$ and the standard deviation $S_{-}(=) 2.87$, the coefficient of variation obtained was C.V. $=26.48 \%$.

The standard deviation indicates that the points or notes of the students in knowledge about Environmental issues are dispersed in 2.87 points, that is to say that their dispersion is low, they are not very far from the average that is 10.84 . The Variation coefficient indicates that all students' grades on average vary by $26 \%$ above or below the average, indicating that the data is not widely dispersed.

\section{Results for Spearman correlation and Generalized Linear Mixed Models Test}

Spearman's correlation analysis is shown in Table 6, it is shown that the correlation between the variables is low, although this test is not significant $(p>0.05)$.

(Continue...) 
Table 6 - Spearman's correlation of Frecuency and Number of Courses

\begin{tabular}{lcccc}
\hline \multicolumn{1}{c}{ Variable(1) } & Variable(2) & $\mathbf{n}$ & Spearman & p-value \\
\hline Frecuency & $\begin{array}{c}\text { Number of } \\
\text { Courses }\end{array}$ & 14 & -0.13 & 0.6497 \\
\hline Notas & $\begin{array}{c}\text { Number of } \\
\text { Courses }\end{array}$ & 14 & 0.15 & 0.6188 \\
\hline
\end{tabular}

In the case of the Wald test it can be observed that there is no significant relationship between the number of courses and the average absolute frequencies reported $(p>0.05)$ while in the case of the Shapiro-Wilks test it is not ruled out that the data come from a normal distribution.

Table 7. Wald test results and Shapiro-Wilks test.

\begin{tabular}{ccccc}
\hline \multicolumn{5}{c}{ Wald test results } \\
\hline Source & numDF & denDF & F-value & p-value \\
\hline \# Courses & 5 & 8 & 0.72 & 0.6262 \\
\hline
\end{tabular}

\begin{tabular}{lccccc}
\hline \multicolumn{7}{c}{ Shapiro-Wilks } \\
\hline Variable & N & Mean & S.D & $\mathbf{W}^{*}$ & $\begin{array}{c}\text { p-value } \\
\text { unilateral) }\end{array}$ \\
\hline \% Courses & 14 & 2.95 & 2.14 & 0.9 & 0.199 \\
\hline \%Assessment & 14 & 7.14 & 4.63 & 0.9 & 0.235 \\
\hline
\end{tabular}

From 15 curricula studied by Professional career of the San Pedro University, Sullana subsidiary, it was found that the careers with the highest environmental content are Agronomy and Architecture and Urbanism. The first with 5 courses and the second with 4 courses followed by the Primary Education career that includes only 3 courses related to the environmental issue. The rest of the careers have one or two courses. These curricular components allow the San Pedro University Sullana subsidiary to meet the regulatory requirements contained in Law 28044 and follow the guidelines of the National 
Environmental Education Policy (2012), in terms of professional training of environmental content. In principle, this result is restricted, since it only expresses the formality of the curricular content, without presenting the impacts of the environmental axis in the curricula and in the performance of academic life, in the sense expressed by Pulido and Olivera (2018), who, evaluating didactic approaches and pedagogical strategies, demonstrate the insufficiency of the formal presence of environmental courses in the curriculum, in cases where they fail to urge tangible pro-environmental actions by the student body.

In December 2018, the report of the Ranking of Sustainable Universities was issued according to the Interuniversity Environmental Network Report (2018), where San Pedro University didn't qualify. Both indicators - normative formality and non-ranking in the qualification, express the disparity between the satisfaction of regulatory imperatives in environmental matters and the integration of institutionalized environmental behaviors by the San Pedro University Sullana subsidiary. The classification exclusion is an indicator of the prevalence of formal approaches oriented towards the minimum satisfaction of regulatory imperatives, which is confirmed in the low levels of environmental practices at the University of San Pedro, Sullana subsidiary.

This first result is consistent with those obtained by Msengi et al., (2019) who identified the disparity between curricular content and university eco-sustainability practices, where most students do not perform environmental actions, beyond expressing concern about the issue, resulting in low levels of environmental proactivity, as identified by Richard and Adams (2011). Poskus's research (2019) obtained equivalent results in the case of Lithuanian university students, among whom the provisions of need in energy consumption prevail over value provisions in terms of environmental sustainability. The student is concerned with the environment, but does not deal with proposing solutions.

The evaluation indicated that $70.74 \%$ of the students surveyed at Universidad San Pedro subsidiary Sullana are below the range of 12 points on the rating scale, in relation to the level of environmental knowledge. This indicates that two thirds of the students have low levels of environmental knowledge. This result is compatible with the results obtained by Orange et al., (2018) who diagnosed that the level of environmental knowledge of Brazilian Federal University students is below average, coupled with the fact that the 
environmental knowledge they dominate comes from family and community experiences, decreasing the level of knowledge when it reaches the theme includes the social and global.

The verification of the alternative hypothesis of this research, which states that the curriculum of the San Pedro University, Sullana subsidiary doesn't significantly influence the level of environmental knowledge of its undergraduate students, 2017, becomes two complementary interpretations. The first is that the satisfaction of the regulatory formality required by the Ministry of Education of Peru, of incorporating courses of environmental interest in the professional careers curricula, is insufficient to influence the level of environmental knowledge of its undergraduate students. In that sense, Leal et al., (2018) through the gathering of information in 7 countries, concluded that the transformation of the reference frameworks, meanings and experiences that allow the holistic integration of the fundamentals of sustainability at the university level is necessary, as the normative formality anchored in obsolete references hinder the development of pro-environmental attitudes and actions.

The second is that the level of environmental knowledge of university students is associated with multiple factors, different and / or complementary to the curricular contents of professional careers. In this sense, studies referring to Peruvian university students from Carhuapoma and Juárez (2015) and Álvarez et al., (2018) diachronically achieve results in accordance with those achieved in this study. Carhuapoma and Juárez (2015) focused the study on values, Álvarez et al., on behavior and referents of environmental behavior. In both studies the intervention of exogenous factors to academics that influence knowledge and pro-environmental behaviors is observed. Within this framework, the gap in diagnostic evaluation on the transversality of environmental axes in the training of Peruvian professionals, who have knowledge that results in proactive actions and environmental sustainability, is evident.

In addition to the diagnosis of knowledge, it is essential to establish conceptual univocity through the integration and coordination of efforts from university institutions to faculties, teachers, employees and students, with more extensive scope than the accounting of the environmental courses contained in the curricula. With an average of $2.73 \%$ of the courses dedicated to the environmental issue, it follows that the environmental is not a 
priority within the curricular contents of the San Pedro University subsidiary Sullana. However, the evaluation criteria require deepening the specificities of each professional career, which allow overcoming the weaknesses in the evaluation identified by Stough et al., 2018, in the KU Leuven, Faculty of Economics and Business, where it recommends the establishment of specific criteria for the evaluation of the knowledge achieved by each student in environmental matters. Under these criteria it is possible to overcome the misrepresentations which attribute the level of environmental knowledge to the degree, since the development of environmental identities is feasible to be constructed by learning from experiences in the sense indicated by Prevot et al. (2016).

\section{Conclusion}

The level of $2.73 \%$ of the courses dedicated to the environmental issue follows that the environmental is not a priority within the curricular contents of the San Pedro University Sullana subsidiary. The curricular components allow the San Pedro University Sullana subsidiary to meet the regulatory requirements regarding environmental content in the curriculum, which is not expressed in the knowledge level of students in environmental matters. The results of this study show important deficiencies in the knowledge of environmental issues in more than $2 / 3$ of the students.

The gap in the field of diagnostic evaluation on the transversality of the environmental axes in the training of Peruvian professionals needs to be addressed in order to train students with knowledge that leads to proactive actions and environmental sustainability during their university and professional life. To achieve this, it is essential to establish conceptual univocity through the integration and coordination of efforts from university institutions to faculties, teachers, employees and students, with more extensive scope than the accounting of the environmental courses contained in the curricula.

\section{References}

Agenda Perú. Perú, agenda y estrategia para el siglo 21. Lima (Perú): Agenda Peru. 2000. 343 p. 
ÁlVAREZ $A$, LÓPEZ $D$, \& CHAFLOQUE R. Conducta ambiental en estudiantes universitarios de Perú Un estudio nacional en estudiantes de ciencias empresariales e ingeniería. Lima: Fondo Editorial USMP. 2018. 145 p.

APARICIO J, RODRIGUEZ C, BELTRAN J, \& SAMPEDRO L. Transversalidad del eje Medio Ambiental en la Educación Superior. RelbCi. 2014; 1(1): 163 - 172.

CARHUAPOMA Y, \& JUAREZ P. Pro environmental values, attitudes and behaviors in college students of Lima - Perú. Rev Per Obst Enf. 2015; 11(1): 1-7.

CONDOR E. Dimensión ambiental en la formación profesional de los estudiantes de la Facultad de Educación de la Universidad Nacional de Huancavelica. Educ. 2018; 27(53): 4156.

ESTRADA L, \& TOJAR J. College Student Knowledge and Attitudes Related to Sustainability Education and Environmental Health. Procedia Soc Behav Sci. 2017; 237:386-392.

FISCHER D, JENSSEN S, \& TAPPESER V. Getting an empirical hold of the sustainable university: a comparative analysis of evaluation frameworks across 12 contemporary sustainability assessment tools. Assess Eval High Educ. 2015; 40(6): 785-800.

HOOVER E, \& HARDER M. What lies beneath the surface? The hidden complexities of organizational change for sustainability in higher education. J. Clean. Prod. 2015; 106: 175188.

Intergovernmental Panel on Climate Change. Special Report: Global Warming de $1.5^{\circ}$. Special Report: Global Warming de 1.5 ${ }^{\circ}$ Switzerland: IPCC.2018. 32 p.

JACKSON L, PANG M, BROWN E, CAIN S, DINGLE C, \& BONEBRAKE T. Environmental attitudes and behaviors among secondary students in Hong Kong. IJCED. 2016; 18(2): 7080 .

LEAL W, RAATH S, LAZARINNI B, VARGAS V, de SOUZA L, ANHOLON R,...ORLOVIC V. The role of transformation in learning and education for sustainability. J. Clean. Prod. 2018; 199: $286-295$

LIARAKOU G, KOSTELOU E., \& GAVRILAKIS C. Environmental volunteers: Factors influencing their involvement in environmental action. Environ Educ Res.2011; 17(5):651-673.

MAHMOOD A, HUSSAIN T, ALI E. Global warming awareness among the University of Bahrain science students. J. Assoc. Arab Univ. Basic Appl. Sci. 2017; 22:9-16

Ministerio de Educación del Perú. Política Nacional de Educación Ambiental. Lima: Ministerio del Ambiente. 2012. 41 p.

MSENGI I, DOE R, WILSON T, FOWLER D, WIGGINTON C, OLORUNYOMI S, ...MOREL R. Assessment of knowledge and awareness of "sustainability" initiatives among college students. Renew. Energy Environ. Sustain. 2019; 4(6):1-11. 
ORANGES L, ETIENNE A, SOARES M, \& DUARTE V. Students' knowledge of sustainability issues in higher education. Lat. Am. J. Manag. Sustain. Dev. 2018; 4(1):24-40

POSKUS M. Investigating pro-Environmental Behaviors of Lithuanian University Students. Curr Psychol. 2018; 37(1): 225-233.

PRÉVOT A, CLAYTON S, \& MATHEVET R. The relationship of childhood upbringing and university degree program to environmental identity: experience in nature matters. Environ Educ Res. 2016; 24 (2): 263-279.

PULIDO V, \& OLIVERA E. Aportes pedagógicos a la educación ambiental: una perspectiva teórica. Rev Inv Altoandina. 2018; 20(3): 333-346.

RAUF N, ZAKARIA S, \& RAZMAN M. Strategic issues on primary students' knowledge towards sustainability of human habitat and environment. J. Food, Agri. Environ. 2017; 15(1): 61-63.

Red Ambiental Interuniversitaria 2018. Reporte de sostenibilidad ambiental en universidades peruanas 2018. Lima: Secretaria Técnica - Red Ambiental Interuniversitaria. 2018. $36 \mathrm{p}$.

ROSENTRATER K, \& BURKE B.. University Students and Sustainability. Part 1: Attitudes, Perceptions, and Habits. J. Sust. Educ. 2017; 16:220-247

STOUGH T, CEULEMANS K, LAMBRECHTS W, \& CAPPUYNS V. Assessing Sustainability in higher education curricula: a critical reflection on validity issues. J. Clean. Prod. 2018; 172: 4456-4466.

United Nations Framework Convention on Climate Change. Climate Change Annual Report. Luxenbourg: UN. 2018. 62 p. 